\title{
The Central Freight Bureau of Tanzania
}

\author{
by Costa Ricky Mahalu
}

\section{The Developing Countries and World Shipping}

\section{(A) Why a Freight Bureau or a Shippers' Council:}

Despite the fact that their share in world seaborne cargo is 61 percent, the Less Developing Countries (LDCs) own less than 8 percent of the world's fleet. The contrast is particularly marked in the bulk trades where LDCs export 90 percent of tanker cargoes and over one third of the main dry bulk cargoes. In this sphere they own less than 6 percent of the world fleet of tankers and bulk carriers ${ }^{1}$. Their reliance on ocean transport is very heavy and in most cases 90 percent of their external trade is sea-borne. They have, thus, to reckon with the established interests of traditional carriers which more than of ten do prevail and injure the economic interests of these new states. The LDCs are aspiring to attain some measures of control over their cargoes and eventually establish themselves as merchant carriers. These aspirations have been increasing in intensity in the past two decades, a period which saw many of these countries achieving their political independence.

A major concern to these states has been the level and unstable nature of freight rates. In fact any increase in freight rates means both paying more for imports as well as reduction in receipt for exports. High freight rates as often experienced by these states have an adverse effect on their balance-of-payments. Usually increase in freight rates reflects increases in prices of ships and fuel, repair costs, insurance charges, the rising level of steve doring, costs in trading and unloading of cargoes etc. This is even more aggravated by the inflationary trends around the world. These situations hit the LDCs very badly, in that most of their exports are composed of basically primary commodities or semi-manufactured goods. The freight rates for these goods keep on rising because of the above mentioned reasons and unfortunately too, the prices for their primary commoditiers are not that stable. They keep on falling due to competition among themselves or sometimes competition from synthetics. This situation assures them one thing - law foreign receipts. This position is even more aggravated by the use of foreign shipping servies. Hence the noble desire to change the international aspect of shipping through negotiated compromises between these new states and the traditional maritime states.

Attempts through international forums like the UNCTAD's Committee on Shipping to regulate the international shipping activities in a more equitable form are very promising. Through the UNCTAD's Committee on shipping the freight problems of the LDCs have been consistently reviewed with the intention to establishing a just maritime order ${ }^{2}$.

See UNCTAD document TD/222 UNCTAD V. Merchant fleet development para 1.

2 See UN. General Assembly Res. 3201 (S-VI) and 3202 (D-VI). 
The Convention on the Code of Conduct for Liner Conference a major "achievement" by the UNCTAD's, when in force shall demarcate the lengths of the cargo reservation procedures, and the questions of consultation machinery etc., as far as the liner trade is concerned. In this case every signatory shall be entitled to carry 40 percent of his external trade in his own vessels, 40 percent in the ships of other nations he trades with, and 20 percent is entitled to cross traders, that is vessels not involved in their national trade but that of others ${ }^{3}$. The pressing question here shall be, whether the LDCs have the capacity to lift their 40 percent in their national bottoms.

The LDCs make a large group of shippers if one examines their contribution in the world sea-borne trade, comparing it with their share of the world fleet. The frequent rise in freight and the way these rates are formed, especially without even consulting their shipping interests is a source of constant friction between the LDCs and the activities of the Conference lines. Obviously as sovereign states they feel that they should be consulted (at least) in issues surrounding their economic interests and the welfare of their peoples. After all they provide the cargo and thus, important partners in this trade! Unstable rates, formulated arbitrarily are a hovering tragedy as far as their purchasing power abroad is concerned. It is, thus, strongly felt that participation in the shipping activities, even in the initial stages of cargo controlling, could at least assure them rights and powers to negotiate effectively with conference lines making their economic interests recognisable. The protection of such interests could be done through the organisation of shippers into councils not with the intention of confronting conferences, but discuss vital issues surrounding and affecting their trade as business partners, since neither can survive without the other. Consultations and negotiations could be initiated in a number of things, especially on the question of the formation of freight rates, surcharges, bunker and currency adjustment factors, etc., and what factors have to be taken into consideration before a final agreement on the rates is approached ${ }^{4}$. That is the Shippers Council.

The stablishment of a freight bureau should be viewed as a means of protecting shippers in the above indicated problems. Here, the shipper aspires to have much more controll over the cargoes in his ports and the allocation of the cargoes composing his external trade to ocean going vessels. Of importance is also his intention to induce negotiations or consultations on conference lines or other shipowners as far as the question of unstable but rising freight rates, surcharges etc is concerned. In most LDCs such institutions i. e. Shippers' Councils or Central Freight Bureaus are State organisation, representing in most cases state or public cargo interests. One reads the various national shipping policies in their constituting instruments. In this way conference lines deal with Sovereign States, directly. The Sovereign States function through such institutions with the hope of influencing, especially, the structure and level of freight rates in order to lessen the impact of high freight rates on their traditional and non-traditional exports. These institu-

3 See The Convention on the Code of Conduct for Liner Conference, Art. 2.

4 See UNCTAD document TD/B/C. 4/176 - "Protection of Shippers' interests. Guidelines for developing countries". 
tions are sometimes regarded as caretakers of potential shipping interests, in the sense development of national merchant fleets of the LDCs.

\section{(B) The Case for Tanzania}

On the 21 January 1981, the Tanzanian National Assembly passed a Bill establishing a Central Freight Bureau that will control export and import cargo through Tanzanian sea-ports. The move to establish such an institution is as seen above - an attempt to protect the interests of the shippers in Tanzania (?) and giving the Tanzanian State some measure of control over her export and import goods. Up to now, all exports are shipped on FOB terms which means the shippers in Tanzania have no control over the cargo under such circumstances. Imports are freighted on C\&F or CIF terms whereby the seller has a great say over the movement of the goods. A change in this system is desired. 90 percent of Tanzanian foreign trade is sea-borne. Over 90 percent of this sea-borne trade is carried in foreign ships with all the implications in terms of dependency, foreign exchange outflows etc. In 1977, so it is reported, Tanzania spent more than Tshs 1.5 billion in freight alone ${ }^{5}$. In November 1980, the Ministry of Trade lamented:

"Tanzania's total foreign trade has a freight element of about Tshs 2.5 billions." ${ }^{6}$

Many outsider shipping lines call at Tanzanian ports. The liner shipping is predominantly a conference business where Tanzania has little or no say in conference decision making. Official tariffs are fixed by the conference. The Tanzanians regard these tariffs as high as well as unstable. The terms of shipments also, as seen above leave the control of shipping and insurance arrangements in foreign hands, totally unaware of the Tanzanian economic capabilities. Hence the Ministry of Trade again:

"Currently, our foreign exchange is facing a lot of threats and as you might have learned that the Conferences lines have unilaterally declared a General Freight Increase (GFI) of $13 \%$. All efforts to negotiate with them ended up in a deadlock. The Conference lines are further and unjustifiably claiming for $15-25 \%$ port surcharge on the Port of Dar es Salaam which is quite fluid at present. Worked out this is likely to raise our freight element by over $25 \%$, thus, Tanzania losing Tshs 625 million over and above the already inflated sum of Tshs 2.5 billion . . . . Furthermore we would like to remind ourselves that the present inflated freight structure in most developing countries is historical, whereby imports bear relatively higher rates than exports do. Tanzania, for instance, pays about $20 \%$ and $10-15 \%$ for imports and exports respectively in order to subsidize the northbound operations and industries in the traditional markets in Europe. This structure was arranged by and continues to benefit the developed economies ..."

5 See Report on the Committee on the Establishment of the Central Freight Bureau (The Report) Directorate of Shipping, Ministry of Communication and Transport - 7 May 1929, page 2.

6 See Letter from Ministry of Trade to the Exporters and Importers Mainland Tanzania - Ref. VVB/S/ M 110/S dated 28-11-80, oage 1 .

7 Ibid page 1 . 
The powerlessness to control inward and outward freight is now being little tolerated. The only remaining alternative is the building up of a bargaining power - "A starting stage is with imports which we have, with few exceptions, a full jurisdiction over them as buyers ${ }^{\prime}{ }^{8}$. The suggested remedy from this predicament is the purchasing of imports on FOB terms and personally negotiate and nominate competetive ocean carriers in shipping the cargoes from various sources to Tanzania. Exporters should try to sell - "on CIF terms and demonstrate to their buyers that they can effectively and efficiently discharge their duties within a reasonable time and cost . . ." 9 .

The spirit behind the Central Freight Bureau Bill could possibly be as anticipated by this letter from the Ministry of Trade, of fering and encouraging shippers the adaption of new strategies. The Central Freight Bureau comes in an attempt to controll cargoes generated by Tanzanias foreign trade (?) and proceed to create a favourable environment of many other segments of the national economy including the expansion of Tanzanias merchant marine; the development of shipyards and other shipping facilities, insurance etc. ${ }^{10}$. The Central Freight Bureau through generalizing FOB terms, so it is hoped, will reduce the cost of inward transportation by negotiating lower freight rates; bringing the Conference rebates to Tanzania instead of letting them go to European middle men". The Central Freight Bureau, it is again hoped, will reduce or eliminate surcharges; reduce the cost of outward transportation through negotiated freight rates; ensure more cargo for national ships and hence ensure their profitability ${ }^{12}$. It is hoped, further, that this will create a favourable environment for further growth of the national merchant marine, thus, promoting a national maritime industry giving ample employment opportunities. The calculated impact of the Bureau on the National Economy is that it will save foreign exchange on import cargo through lower freight rates, the use of national carriers, and earn foreign exchange by the use of these national carriers in other trades ${ }^{13}$. It is again hoped that import cargo purchased under FOB terms carried on foreign ships ensure freight is payable in Tanzania, thus, restricting the drain of foreign exchange.

Tanzania, however, is not the only LDC to embark on such favourable sounding measures. Sri Lanka through Law No. 26 of 1973 established a Central Freight Bureau (perhaps a very motivating example for Tanzania). The effectiveness of the Sri Lanka Central Freight Bureau is commendable. The situation in Sri Lanka, however, is a little different from that of Tanzania. Even during the colonial era, there were some measures of cargo preference in the then Ceylon, as far as the export of rubber loads was concerned,

8 Ibid page 2.

9 Ibid.

10 See The Report - page 15.

11 That means, there shall be a $10 \%$ saving in the freight bill currently enjoyed by foreign sellers.

12 The SINOTASHIP has been able to lift less than $1 \%$ of Tanzanias cargoes.

This company, jointly owned by Tanzania and the Peoples Republic of China, operates a semi liner-Tramp service.

13 The Then, Minister for Communication and Transport Mr. Augustine Muringira explained in the National Asembly that Tanzania does and have the capability to freight even $10 \%$ of her cargoes in her national ships See Daily news 22 January 1981 - "House passes Freight Bill". 
for the colonial ships operating in this area. The administration of such activities has been continued by the Bureau in Sri Lanka as far as her exports are concerned. Indeed she has managed to establish and expand her merchant shipping industry. Ivory coast operates a Council of Shippers established by Ivory Coast Act no. 69-240 of June 1969. The objects of this Council is to work towards a reduction of shipping rates, through negotiations with shipping companies, shipowners and shipping conferences, the examination of all practical and legal problems directly linked with shipping rates, with a view to finding adequate solutions ${ }^{14}$. In Cameroun a Shippers Council is established by decree no. 75/118 of February 1975 with an intention to work with a view to stabilizing or reducing the rate of Sea-Transport freight; to study all solutions likely to enable the grouping of freight to ensure the carriage of profitable cargo without prejudice to the interest of the foreign trade of Cameroon ... To attain these objectives, it shall be empowered to negotiate with shipowners and managers and shipping conferences ${ }^{15}$. Decree no. 75/209 of November 1923 indicates very clearly the Cameroonian national shipping policy, which is in line with the proposed Code of Conduct for Liner conferences. The Sri Lanka Central Freight Bureau, and that of Tanzania, and the Shippers Councils in Ivory Coast and Cameroon, are reflective of aspirations to establish effective and efficient machinery to promote and facilitate consultations on mutual problems, between shippers, Governments and the Conference Lines.

\section{Tanzanias Central Freight Bureau}

(A) The Institution: Objects and Reasons stated as a driving force for the creation of the Bureau, as the Billprovides, is in respect of cargoes generated from Tanzania ${ }^{16}$. That implies that the Bureau's activities are restricted to Tanzanian cargoes. This again indicates that goods affected apart from being generated in Tanzania, are those falling in the category of exports only. We cannot, however, put much meaning in the interpreation of the Bills Objects and Reasons. We have to look at the statute itself. The Bureau is established by Act no. 1 of 1981, whose section 3 gives the Bureau a corporate personality. The functions of the Bureau are provided for in Section 4 (1) and (2). These functions of the Bureau, inter alia, shall be to allocate cargo space on any ocean going vessel, in respect of goods shipped from or to any port in Tanzania; to aggregate goods shipped or intented to be shipped to or from any port in Tanzania; to rationalize shipping services and the availability of vessels for the carriage of goods; to regulate activities of freight forwarders in accordance with national shipping policy; to establish and maintain a system of consultation and cooperation with any written law and having functions related or similar to those of the Bureau for the purposes of promoting or or facilitating:

14 See Article 2 of Act no. 69-240 of June 1969 - Ivory Coast.

15 See Decree No.25/118 of 21 February 1975. Chapter 1 Article 3 and 3 (2). United Republic of Cameroon.

16 See The Tanzanian Central Freight Bureau Bill, No. 4 Bill Supplement, 26 December 1980, p. 48. 
"(i) the development of a national merchant fleet

(ii) the improvement of the facilities and performance of ports;

(iii) the formulation and maintainance of economic freight rates which further the interests fo both shippers and shipowners " 17

Section 4 (2) runs as follows:

"(2) In particular, but without prejudice to the generality of subsection (1) the Bureau may -

(a) centralise the booking of freight cargo space in respect of goods intended to be shipped from any port outside Tanzania or from any port in Tanzania to any destination outside Tanzania;

(b) negotiate with shipowners and shipping lines, individually or collectively on matters relating to freight rates, surcharges, currency and bunker adjustment factors, adequacy, frequency and efficiency of shipping services;

(d) provide or aggange transport and storage of goods;

(e) charter ships for the purpose of its functions;

(g) require any person or body of persons or institutions carrying on the business of shipper, shipowner or shipping agent to furnish to it such information as it may specify relating to the shipment of goods to or from Tanzania";

The Bureau shall have the sole right to book all cargoes coming to or going from the United Republic, along trade routes which are under the jurisdiction of the Bureau except for goods exemted by the Minister under Section 23(1) ${ }^{18}$

\section{Jurisdiction of the Bureau}

The question on the jurisdiction of the Bureau, as far as cargoes going through Tanzanian ports is very important. Apparently this important aspect of the Bureau is not precisely defined in the Act. One wonders at the generality of Section 4 (1) (a) as far as the function of the Bureau is concerned - i. e. the Bureau shall allocate cargo space on any ocean going vessel in respect of goods shipped from or to any port in Tanzania. The Tanzanian ports are not solely for Tanzanian exports and imports. The Dar es Salaam port, for instance, has a large and potentially richt hinterland, made of four possible and active users of the port as land-locked countries. These are Burundi, Ruanda, Zaire and Zambia. The cargo handled in Tanzanian ports is, thus, not all of it Tanzanian. A good example is the dry cargoes handled by the Dar es Salaam port in 1980. Imports accounted for about 1.250 million tons, whereas exports accounted for 280.000 tons. The vast majority of this cargo was non-Tanzanian ${ }^{19}$. Zambian goods are served by the Tazara

17 Act no. 1 of 1981. Tanzanian Central Freight Bureau - Sec. 4 (1) (f).

18 See Act no. 1 of 1981 Section 19 (2).

19 Information about tonnage handled by the Dar es Salaam port in 1980 was being prepared at the time of writing this paper. Any lack of precision is greatly regretted and a responsibility of the Author. It takes, however, rather a long time to compile the precise statistics. The figures above attempt to show the situation at Dar es Salaam port. 
from Kapiri Mposhi to Dar es Salaam port. Road connection is also available. Burundi and Ruanda do sometimes use the central transport corridor, i. e. the central railway line from Dar es Salaam to Kigoma, on the shores of Lake Tanganyika. Zaire is also in a favourable position to be served by the central transport corridor to the Indian Ocean. Obviously these countries do claim their right of access to and from the sea - (The Indian Ocean). The functions of the Bureau if not well defined are likely to present a difficult situation as far as maritime interests of these land-locked states are concerned. They as shippers, feel also the need, it can be correoly assumed, to exercise some measures of control over their export and import cargoes. Unless it is well explained and so provided that the Bureau shall in its functions represent the maritime interests of these countries, a clearer position as far as the cargoes of these states through Tanzanian ports is lacking. The above cited section complicates the problem as far as the jurisdiction of the Bureau is concerned. The allocation of cargoes on any ocean going vessel, in respect of goods shipped from or to any port in Tanzania, indicates that the cargo does not have to be Tanzanian, but all cargo shipped from or to any port in Tanzania. It could, thus, be Zambian cargo, or Ruandese, or Zairean cargo. As long as it is shipped from or to any Tanzanian port the Bureau shall act.

In section 5 (2) (a) the Bureau may "centralize the booking of freight or cargo space in respect of goods intended to be shipped from any port outside Tanzania to any destination in Tanzania .... . This far, the situation is defined - the goods shipped to any destination in Tanzania unless otherwise stated, they are Tanzanian cargoes. The other half of the subsection is confusing -" . . . or from any port in Tanzania to any destination outside Tanzania". Obviously not necessarily Tanzanian exports! Section 19 (2) is also very disturbingly vague. Here it is provided that the Bureau shall have the sole right to book all cargo coming to or going from the United Republic along trade routes which are under the jurisdiction of the Bureau. When one compares this last cited section and the generality in Section 4, a need for a clearer definition of the Bureau's jurisdiction is more than imperative.

\section{Functions of the Bureau}

Going through the provisions of the Act one wonders whethers the Bureau in its form is a shipping agent, a shippers' organisation or a shipping company. The allocation of cargo space on ocean going vessels, the aggregation of goods, centralizing the booking of freight or cargo space, the providing of or arrangement for transport and storage of goods, are wide range of activities pursued by shipping agents and other freight forwarders. The negotiating with shipowners and shipping lines on matters relating to freight rates, surcharges, currency and bunker adjustment factors, adequacy, frequency and efficiency of shipping services, are activities associated with the workings of a shippers' organisation, or Council. The development of a merchant fleet or the chartering of ships for its functions, are just the activities of a shipping company. It is vague really and too 
general as far as the actual business status of the Bureau is concerned. This problem would have been solved by a provision emphasing the actual roles of the Bureau in very precise terms. One has simply got to read the Report and compare it with the Act, to see the extent of its vagueness.

\section{Administration of the Bureau}

The Board of the Bureau provided under Section 5 (1) shall be responsible for the performance of functions and management of the affairs of the Bureau. This Board may further establish committees from among its members and delegate any functions of the Board to those Committees. The Chief executive officer of the Bureau is a Director-General who shall be appointed by the President ${ }^{21}$. In the general administration of the Bure$\mathrm{au}$, and its functions, the Minister for Communication and Transport is given a lot of work. The power of the Minister in the activities of the Bureau is too frequently referred to, that the autonomy of this institution - as a business institution - is no more than that of a ministerial department. The Minister, to cite but a few examples, has to specify goods and trade routes which may fall under the jurisdiction of the Bureau and even prescribe procedures relating to freight bookings etc. (see Section 8, 10, 19 and 23). This atmosphere, despite the fact that the Bureau has to plan its own business target, as a business institution, trusted with the implementation of national policies, subjects the Bureau to the rigidity accompanied or characterized with ministerial bureaucracy, where decision making is not so snap, to that required in a fast moving business world. One can certainly anticipate irritating delays.

\section{The Bureau and the National Shipping Policy}

The shipping policy embodying Tanzanian policies is no where to be found in the Act. The Act is simply an establishing instrument - and it really does that. In its 5 Parts and 23 sections, only one section is loosely and generally devoted to the nature and activities of the Bureau. There is a sweeping mention in Section 4 (1) (d) on the national shipping policy, as far as the regulating of activities of freight forwarders is concerned. Still no single section explains Tanzanian national shipping policy upon which the functions of the Bureau shall be based. Perhaps like in Cameroon this will be provided in a separate instrument ${ }^{22}$.

The Report, referred above, hints about cargo reservation i. e. preference to national bottoms. The Act runs - the Bureau shall wallocate cargo space on any ocean going vessel ...."123. One simply asks where ist the question of priorities?

20 See Act no. 11081 Sectiōn 5 (5) ans Section 17.

21 Ibid Section 6.

22 The Cameroon Decree no. 75/209 of November 1925.

23 Act No. 1 of 1981, Section 4 (1) (a). 
Deferred rebates are not liked by some officials in Tanzania. It is true that these deferred rebates indicate and prolong a monopolistic aspect or practice of the Conferences, thus, tying the shippers to them. The shipper has no choice but to use the conference services with the 10 percent discount in anticipation, or simply in fear of being black listed. It is still anticipated that through FOB terms of shipment for imports, the buyer or shipper in Tanzania shall now pocket the 10 percent or reduce the weight of a freight rate, thus saving some foreign exchange. It is not a matter of doing away with the system. It is a matter of changing the structure of the system so that the benefits should now accrue to Tanzanian shippers. At least this is what one gathers from the Report. The Act is vague. There exists, up to now, certain loyalty agreement between shipping lines and shippers. Despite the functions of the Bureau as stated above, these agreements may remain. It is only, and if in the Minister's opinion, the public interest so requires, may he abolish any existing loyalty agreement, or simply impose restrictions on the terms or scope of such agreements ${ }^{24}$. Still section 19 (2) provides that the Bureau shall have sole right to book all cargo coming to or going from the United Republic.

\section{Impact of the Bureau on Other Institutions}

The Bureau is established as a purely Tanzanian Institution. Its relationship with the Inter-governmental Standing Committee on Shipping (ISCOS) is not specifically mentioned. Perhaps there is no need. ISCOS has been negotiating with the Conference lines serving the East Africa trade. It has been representing four states, Kenya, Uganda and Zambia. These states had until recently owned a shipping line jointly. The East Africa National Shipping line (EANSL) ran into financial problems (as surface problems) and was liquidated. ISCOS has been negotiating with conference lines on matters regarding freight rates, surcharges, currency and bunker adjustment factors etc. The Report regards ISCOS, however, as follows:

". . . ISCOS since its inception, has not been very effective. Apart from reasons of lack of capability to discharge its responsibilities, the most vital reason has been the fact that the countries concerned do not exercise any degree of control on their trade cargoes", ${ }^{25}$

Talking to ISCOS officials in Mombasa, Kenya, the impression given was in a different form. They said that they were quite confident and pleased with the trend of their activities. They were also happy and pleased with the procedures of negotiations with conference lines. In these procedures, the Conference lines have to discuss their intention to raise freight with ISCOS before announcing them ${ }^{26}$. ISCOS's big achievement, according to $\mathrm{Mr}$. Banda, is the reduction of the once roposed freight rate hikes by 22 percent to 13 percent $^{27}$. Even then ISCOS had wanted a rise by only 11 percent.

24 Act No. 11981 Section 19 (1).

25 The Report pages 4-5.

26 I met Mr. Banda, the General Secretary of ISCOS in Mombasa. Assessing the activities of the Committee, he praised the success they had achieved in dealing with Conference lines - especially the Europe-East Africa Conference.

27 See letter to All Exporters - Importers - from Ministry of Trade-referred in footnote 7. 
One hopes, that the two institutions, vital in their own aspect, one representing a regional aspect, and the other a national will collaborate and cooperate in the most effective way. ISCOS advantages are that it has the experience, with which through consultation and cooperation it can impart to the Bureau.

There are also elements of the Bureau's functions which may tread into the National Shipping Agency Company (NASACO) activities: It is very important to demarcate the spheres of functions between the Bureau and NASACO in the most clear terms, in the establishing instrument. NASACO has established a high reputation in its activities to both shipowners and shippers in Tanzania and abroad. It is, without doubts, the leading Tanzanian institution in ocean transport activities, and has some of the most qualified personnel, not to mention experienced ones as far as shipping in Tanzania is concerned. One expects to see that the Act establishing the Bureau, specifically provides for a sort of coordination or cooperation with NASACO just as it refers such cooperation with the Tanzanian Harbours Authority ${ }^{28}$.

The desire indicated in the Report, but hardly seen in the Act, or even Objects and Reasons of the Bill, that of saving foreign exchange through the Bureau's functions is very noble. The changes in the terms of shipments, from CIF for imports to FOB, from FOB for exports to CIF are calculated measures to reach this goal. When deferred rebates flow into Tanzanian hands, that is a form of earning foreign exchange. Even more important is the reduction of the rates, indicating, a saving, as far as the outflow of foreign exchange is concerned, in the buying of shipping services. Constant negotiations induced by Bureau with the various conference lines serving the Tanzanian ports, aiming at reasonable rates, is also another form of securing stable low rates. But to secure low rates, Tanzania has also to improve certain facilities i. e. port facilities for loading and unloading ships, storage facilities, and the internal infrastructure for the sake of having facilities, an ef ficient atmosphere, causing no delay for ships calling at Tanzanian ports. Such delays are the sources of the frequent surcharges and other rate increases.

There are, however, no means indicated in the Act for determining shipping lines quoting lower rates. In the Act it is probably desired that any ocean going vessel, quoting lower rates shall be (impliedly) given priority.

This can, possibly, save the outflow of foreign exchange, but there is always a danger to this practice. A shipowner, quoting lower prices to undercut others (a blessing for the shippers) thus, winning the favours in the region of his activities, sooner or later faces relaties. When he has a monopoly in the region, his rates will definately respond to the economic costs required to run his vessels. Unless of course, the shipowner has a very heavily subsidized fleet working on non commercial principles but political strategies. Negotiations between shippers and shipowners and shipping lines is the best form and means of stabilising rates. The bad public relations characteristic of conference lines is always a hinderance in these negotiations. Their reluctancy to grasp the genuine problems experienced by the poor shippers complicates the situation and sometimes invites conflicts.

28 See Act No. 11981 Section 4 (2) (c). 
This is where unilateral tough solutions are sometimes embarked upon by the poor sovereign states. The aim is to reduce the foreign exchange out flow. Policies used by the Bureau in pursuit of this aim shall depend fully on its relationship with shipowners.

The reserving of national cargo for national fleet is also one way of reducing the out flow of foreign exchange. One wonders at the capacity, for instance of the SINOTASHIP, to involve itself actively in the lifting of the national cargoes.

Payment of freights and other rates in Tanzania currency, if the Bureau can actually negotiate on that, shall be agreat foreign exchange saving mechanism.

The earning of foreign exchange is related through the use of the national fleet in the lifting of other trades - i. e. cross trading. A number of countries have been earning al large part of their foreign exchange through cross trading, Norway being the most of them, before her oil boom. The problem here is that, there is no such an efficient fleet, (so far) in Tanzania, perhaps later on. Even then, when flag preference is practised strictly, chances of retalliation are likely to be many. The operation of liner services is profitable if the way port trade is included. It is through the way port trade where some foreign exchange could be earned. Otherwise a source to market service is the best in the bulk trades and dangerous for Tanzania's liner trade. This fact has to be taken into consideration. At the same time, it must be known that the development of a merchant fleet needs all the protection. This can be done effectively through flag discrimination. The industry in its infant stage needs protection. Problems occur if it has to play the cross trading services.

The formulating of higher freight rates by the national merchnat fleet, in order to earn foreign exchange, might bring the line into disfavour as far as shippers interests are concerned. Yet, this is what has been happening in the trades of West Africa. Cameroon and Ivory Coast, have been tempted to look at the higher gains coming from operating merchant fleets. The temptation to raise freight rates brings forward another bad position. The buyer, finds that the goods involved in the trade are very costly due to the high rates. He thus looks for other cheaper sources where the freight rates are not at all high ${ }^{29}$. The European buyer can afford an alternative, because he has many sources. At the moment the African buyer cannot.

(B) The Law: The Law providing for the facilities setting up the Bureau, did not take into consideration one important fact - the fact that the Bureau in its activities shall deal with various foreign interests in their private capacity.

There is thus a naked omission of a conflict of law provision. This is a potential problem area should the Bureau start its function. The sooner this legal vacuum is filled up, the Courts will not be faced with controversies.

Section 20 (3) provides as follows:

"(3) Where a shipper, shipowner or shipping agent refuses to pay to the Bureau within days after demand any sum which is required to pay as a charge or commission under

29 See "Multelaterale Seeverkehrsprobleme mit Afrika" in Afrika-Kollegium, 4. Symposium 1979, 6 April 1979, Hamburg, pages 16-23. 
this section, such sum may on application made by the Bureau to a court having jurisdiction over the last place of business or residence of such shipper, shipowner or shipping agent ..."

The question of conflict here is very narrow and limited only to the failure to pay a charge or commission under the Act to the Bureau. Obviously other questions involving conflict of laws might not have been anticipated by the drafters of the Bill.

Going through the Act, there is a constant use of the word "may" on very important functions which makes one wonder as to the actual seriousness of the Bureau. The Bureau may centralize the booking of freight; may negotiate with shipowners - to mention but a few examples ${ }^{30}$. The legal mind regards the word 'may' as a last alternative in changing a certain given status quo. The consistent use of this word in major provisions, might jeopardize the effectiveness of the Bureau.

Conclusion

The Bureau is an experiment to many other developing states. They wish to see its success or failures. It is a buoyant institution, expressing genuine aspirations by a developing state to exercise some measures of control on its foreign trade. Its undefined jurisdiction and general functions may give it too much or too little power. It would have been much better if it had started with a specific problem and proceed to solving it, eg. the control of export cargo, and see how the problems in this sphere of activity can be solved. Slowly could it proceed into other aspects of shipping, armed with concrete years of experience and capability.

Obviously the Bureau shall experience various forms of reactions, but one has to know it is a positive step towards the creation of a bargaining power. It is today a national institution, but a regional one tomorrow.

\author{
A BILL \\ for \\ An Act to establish the Tanzania Central Freight Bureau and for matters connected \\ with, and incidental to the establishment of the Bureau \\ Enacted by the Parliament of the United Republic of Tanzania.
}

\title{
PART I
}

Preliminary

I. This Act may be cited as the Tanzania Central Freight Bureau Act, 1981, and shall come into operation on such date as the Minister may, by natice in the Gazette, appoint. 
2. In this Act, unless the context requires otherwise -

"agent" means a person of body of persons employed as agents by the Bureau whether locally or outside Tanzania;

"bill of lading" means a document which evidences a contract of carriage by sea and the taking over or loading of the goods by the carrier, by which a carrier undertakes to deliver the goods against the surrender of the document and the provision in the document that the goods are to be delivered to the order the named person or to bearer, constitutes such undertaking;

"Board" means the Board of Directors of the Central Freight Bureau established under section 5;

"the Bureau" means the Tanzania Central Freight Bureau established by section 3; "consignee" means a person entitled to take delivery of the goods;

"contract of carriage by sea" means any contract whereby the carrier undertakes against payment of freight to carry goods by sea from one port to other and includes carriage by sea in consideration of which such shipper agrees to shipgoods exclusively in ships owned by such owner;

"contract rate" means a lower freight rate agreed to between a shiper and a shipowner in respect of carriage of goods by sea in consideration of which such shipper agrees to shipgoods exclusively in ships owned by such owner;

"Director-General" means, the Director-General of the Tanzania Central Freight Bureau appointed under section 6;

"freight" means charge for transporting goods by ship;

"freight rates" include contract rates, general rates and promotional rates;

"goods" includes live animals and such article of transport or packaging if supplied by the shipper;

"loyalty agreement" means an agreement or arrangement between Liner Conferences and shippers or their agents whereby shippers in the United Republic confine the maritime transportation of all or part of their goods to a particular Liner Conference; "Minister" means the Minister for the time being responsible for shipping matters; "national vessels" include vessels owned either wholly by the Government of the United Republic of Tanzania, Gouvernment of Zanzibar, Tanzania Private persons or vessels owned jointly between the Government of the United Republic of Tanzania or the Government of Zanzibar and other persons whether lokal or foreign;

"promotional freight rate" means a rate for the carriage of non-traditional exports; "shipper" means any person by whom or in whose name or on whose behalf a contract of carriage of goods by sea has been concluded with a carrier, or any person by whom or on whose behalf the goods are actually delivered to the carrier in relation to the contract of carriage by sea;

"Special Shipping Fund" means a fund established by the Board under section 11. 


\section{PART II}

\section{The Tanzania Central Freight Bureau}

3.-(1) There is hereby established a body corporate to be known as the Tanzania Central Freight Bureau.

(2) The Bureau shall -

(a) have perpetual succession and an official seal;

(b) in its corporate name, be capable of suing and being sued;

(c) subject to the provisions of this Act, be capable of holding, purchasing or asquiring in any other way, any movable or immovable property, and of disposing of any of its property.

4.-(1) The functions of the Bureau shall be -

(a) to allocate of cargo space on any ocean going vessel, in respect of goods shipped from or to any port in Tanzania;

(b) to aggregate goods shipped or intended to be shipped to or from any port in Tanzania;

(c) to rationalize shipping services and the availability of vessels for the carriage of goods;

(d) to regulate activities of freight forwarders in accordance with national shipping policy;

(e) to undertake research in matters relating to shipping services and freight rates;

(f) to establish and maintain a system of consultation and co-operation with any person or body of persons established by or under any written law and having functions related or similar to those of the Bureau for the purposes of promoting or facilitating -

(i) the development of a national merchant fleet;

(ii) the improvement of the facilities and performance of ports;

(iii) the formulation and maintainance of economic freight rates which further the interests of both shippers and ship owners.

(2) In particular, but without prejudice to the generality of subsection (1) the Bureau may -

(a) centralize the booking of freight or cargo space in respect of goods intended to be shipped from any port outside Tanzania to any destination in Tanzania or from any port in Tanzania to any destination outside Tanzania;

(b) negotiate with shipowners and shipping lines individually or collectively on matters relating to freight rates surcharges, currency and bunker adjustment factors, adequacy, frequency and efficiency of shipping servies and matters connected with shipping servies;

(c) in consultation with the Tanzania Harbours Authority, established under the Tanzania Harbours Authority Act, 1977, construct, execute, carry out, equip, improve, work, develop, administer, manage or control in the ports of Tanzania, such works and conveniences as may be necessary to facilitate shipment of goods or the discharge and removal of goods from the ports:

(d) provide or arrange for transport and storage of goods; 
(e) charter ships for the purposes of its functions;

(f) levy charges and commissions for any services rendered and facilities provided by the bureau to shippers and shipowners;

(g) require any person or body of persons or institution carrying on the business if shipper, shipowner or shipping agent to furnish to it such information as it may specify relating to the shipment of goods to or from Tanzania;

(h) do any other or thing which may be necessary expedient or desirable for the proper exercise and better carrying out of the functions of the Bureau.

\section{PART III}

\section{Administration}

5.-(1) There shall be established a Board of the Bureau which shall, subject to this Act, be responsible for the performance of functions and management of the affairs of the Bureau.

(2) The provisions of the Schedule to this Act shall have effect in respect of the constitution of the Board, its proceedings and other matters related to it.

(3) Save in the case of matters relating to the of fice and appointment of the Chairman of the Board and the Director-General of Bureau, the Minister may, by order published in the Gazette, amend, add to, vary or replace any of the provisions of the Schedule to this Act.

(4) Subject to section 17, the Board may establish committees from among its members and delegate any functions of the Board to any of those committees.

(5) The Minister may give to the Board directions of a general or specific character regarding the performance by the Bureau of any its functions under this Act, and the Board shall give effect to every such direction given to it.

6. The President shall appoint, upon such terms and conditions as he may specify, a Director-General of the Bureau who shall be the chief executive officer of the Bureau.

7. The Board may from time ti time appoint such number of other employees of the Bureau as it may deem necessary for the proper and efficient conduct of the business and activities of the Bureau.

\section{PART IV}

\section{Financial Provisions}

8. The funds and resources of the Bureau shall sonsist of -

(a) such sums which may derive from the operations of the Bureau;

(b) such funds or assets as may rest in or accrue to the Bureau from other sources by way of grants, gifts, fees or in any other way;

(c) any such sums which the Board may, subject to the provisions of section 10, borrow for the purposes of the Bureau;

(d) such sums as may be provided for a specified purpose by Parliament, either by way of grant or loan. 
9. With the prior approval of the Minister the Board may, from time to time, invest any part of the moneys available in any fund in investments authorized by the Trustees Investments Act, 1967, for investment of any trust fund.

10. With prior approval of the Minister the Board may, from time to time, borrow moneys for the purposes of the Bureau by way of loan or overdraft, and upon such security and such terms and conditions relating to repayment of the principal and payment of interest subject to any direction by the Minister, as the Board may consider fit.

11.-(1) There shall be established within the Bureau a Special Shipping Fund, hereinafter referred to as "the Fund" which shall be applied generally for the advancement of the maritime interests of Tanzania including the expansion of the national merchant fleet, development of ports warehousing facilities and training.

(2) The moneys credited to the Fund shall be held and disbursed separately from the moneys and other funds of the Bureau.

(3) The moneys of the Fund shall be derived from-

(a) such percentum of the funds of the Bureau payable into the Fund as the Board may, with the approval of the Minister determine;

(b) such other sources as may be determined by the Board with the approval of the Minister;

(c) such sums or property as may in any other manner vest in the Bureau for the purposes of the Fund.

(4) The Minister shall, from time to time, and with the consent of the Minister for the time being responsible for Finance determine the projects or programmes in respect of which expenditure shal be incurred on the account of the Fund.

12.-(1) Subject to subsection (2), "financial year" in this Act means any period not exceeding twelve consecutive months designated by the Board as the accounting of the Bureau.

(2) The fist financial year of the Board shall commence on the date when this Act comes into operation and may be of a period longer or shorter than twelve months.

(3) Not less than two months before the beginning of any financial year the Board shall, at its first meeting especially convened for that purpose, pass a detailed budget (in this Act alled the "annual budget") of the amounts respectively -

(a) expected to be received; and

(b) expected to be disbursed by the Board during the financial year.

(4) If in any financial year the Board requires to make any disbursemet not provided for in the annual budget for the year the Board shall, as a meeting, pass a supplementary budget detailing the disbursement.

(5) Forthwith upon the passing of the annual budget or any supplementary budget the Board shall submit the budget to the Minister for his approval.

(6) The Minister shall, upon receipt of the annual budget or supplementary budget, approve or disapprove it or approve it subject to such amendment as he may consider fit.

(7) Where the Minister has approved any annual budget or supplementary budget the budget as approved by him, whether which or without amendment shall be binding on 
the Board which, subject to the provisions of substotion (6), shall confine its disbursement within the items and amounts contained in the applicable estimates as approved by the Minister.

(8) The Board may -

(a) with the sanction in writing of the Minister make disbursement notwichsanding that the disbursement is not provided for in any budget;

(b) from the amount of expenditure provided for in any budget in respect of any item, transfer a sum not exceeding two hundred thousand shillings to any other item contained in the budget;

(c) adjust expenditure limits to take account of circumstances not reasonably foreseable at the time the budget was prepared, subject to submitting a supplementary budget to the Minister within two months of he alteration of expenditure limits becoming neccessary.

13.-(1) The Board shall cause to be provided and kept proper books of accounts and records with respect to -

(a) the receipt and expenditure of moneys by, and other financial transations of, the $\mathrm{Bu}$ reau;

(b) the assets and liabilities of the Bureau, and shall cause to be made out for every financial year a balance sheet and astatement showing detaiis of the income and expenditure of the Bureau and all its assets and liabilities.

(2) Not later than six months after the close of every financial year the accounts including the balance sheet of the Bureau in respect of that financial year, shall be audited by the Tanzania Audit Corporation established by the Tanzania Audit Corporation Act, 1968.

(3) Every audited balance sheet shall be placed before a meeting of the Board and, if adopted by the Board, shall be endorsed with the certificate that it has been adopted.

(4) As soon as the accounts of the Bureau have been audited and adopted by the Board, and, in any case not leter than six months after the audit, the Board shall submit to the Minister a copy of the audited statements made by the auditors.

14. The Board shall, within six months after the close of the financial year, cause to be prepared and submitted to the Minister a report dealing generally with the activities and operations of the bureau during that year and accompanied by

(a) a copy of the audited accounts of the Bureau;

(b) a copy of the auditors report on the accounts; and

(c) such other information as the Minister may direct.

15. The Minister shall, as soon as practicable and, in any case not later than twelve months after the close of a financial year, lay before the National Assembly the following documents in relation to that financial year

(a) a copy of the audited statement of accounts of the Bureau;

(b) a copy of the auditors report; and

(c) a copy of the report by the Board. 


\section{PART V}

\section{Miscellaneous Provisions}

16.-(1) Subject to subsection (2) members of the Board shall be entitled to such remunerat on, feet or allowances for expenses as the Minister may, upon the recommendation of the Board, prescribe from time to time.

(2) No remuneration fees or allowances, except such allowances for expenses as may be expressly authorized by the Minister, shall be paid to any member of the Board who is a public officer.

17.-(1) Subject to the provisions of subsection (6), the Board may, from time to time, by writting under the official seal of the Bureau subject to such terms, conditions and restrictions as it may specify, delegate to any committee of the Board or to any employee of the Bureau, all or any of the functions, powers or duties conferred or imposed by or under this Act on the Board, and where any delegation is so made the delegated function, power or duty may be performed or excercised by the delegate subject to the terms, conditions and restrictions specified by the Board.

(2) The delegation under subsection (1) may be made to the holder of an office under the Bureau specifying the of fice but without naming the holder, and in every case where delegation is so made each successive holder of the office in question and any person who occuples or performs the duty of that office may, without any further auchority, perform or exercise the delegated function, power or duty in accordance with the delegation made by the Board.

(3) The Board may revoke a delegation made by it under this section.

(4) No delegation made under this section shall prevent the Board from itself performing or exercising the function, power or duty delegated.

(5) A delegation made under this section may be published in the Gazette, and upon its being so published shall be judicially noticed and shall be presumed to be in force unless the contrary is proved.

(6) The Board shad not have power under this section to delegate -

(a) its power of delegation; or

(b) the power to approve the annual budget or any supplementary budget, the annual balance sheet or any statement of accounts.

18. Without prejudice to the provisions of section 284a of the Penal Code or the Specified Officers (Recovory of Debis) Act, 1970 or of the Parasatt Emproyee (Recovery of Debis) Act, 1974, no act or things done or emeed to be done, by any person who is a member of the Board or empiyee or agent of the Bureau shall, if done or omitted bona fide in the execition or purported epecution of his duties as the member of the Board or emioyee or agent of the Bureau, subject that person to any action, liabili or demand of any kind.

19.-(1) If in his opinion the public interest so requires, the Minister may, by order published in the Gazette, abolish any existing loyalty agreement or impose restriction on the terms or scope of loyalty agreements which may be entered into by shippers in the United Republic. 
(2) Except for goods exempted by the Minister under section 23 (1), the Bureau shall have the right to book ad cargo coming to or going from the United Republic along trade rouces which are under the jurisdiction of the Bureau.

(3) No person shad be entitled to any payment as compensation for loss of business arising or incurred as ad result of an order restricting to the Bureau the right to book certain cargo, or vesting into the Bureau the sole right to book cargo coming to or going from the United Republic along any trade route.

20.-(1) Charges and commissions may be made by the Bureau for any services rendered or facites provided by the Bureau to shippers ans shipping agents and shalt be fixed by the Board with the approval of the Minister and may be revised from time to time.

(2) Charges and commissions referred to in subsection (1) shall become payable within thirty days after demand by the Bureau.

(3) Where a shipper, shipowner or shipping agent refuses to pay to the Bureau within thirty da after demand any sum which he is sudred to pay as a charge or commission under this section, such a sum may, on application made by the Bureau to acourt having jurisdiction over the last known place of business or residence of such shipper, shipowner or shipping agent be recovered in like manner as a fine imposed by such court.

21.-(1) Where, at the request of a shipper or his agent, and the Bureau books, reserves or abocates cargo space on any vessel, and the shipper or his agent fails or refuses to utilize the whole or part of the space so booked, reserved or adocated, the Bureau may impose a penalty, on the shipper or agent concerned, not exceeding thirty-thousand shillings, and may recover the amount as a civil debt.

(2) The Bureau may, notwithstanding the penalty imposed under subsection (1), recover from the shipper or agent in question, as a divil debt, an amount equivalent to the loss incurred by the Bureau as a result of the default by the shipper or agent.

(3) In any action for the recovery of any amount due to the Bureau under this section, a certificate under the hand of the District-General that that amount is due as a penalty or the amount of the loss incurred by the Bureau, and that the defendant is the person liable to pay the money shall, in the contrary be conclusive evidence of the amount and of its non payment, and that the defendant is the person liable for the payment of the money in question.

(4) Nothing in this section may be construed as precluding the court in any proceeding, from considering and reviewing the amount of the penalty imposed under subsection (1).

22. Any person who commits an offence this Act, for which penalty is not specifically provided elsewhere in this Act, shall be liable on conviction to a fine not exceeding thirty thousand shillings.

23.-(1) The Minister may, from time to time, by order -

(a) specify goods and trade routes which may fall under the jurisdicttion of the Bureau;

(b) exempt goods of any class or description as may be specified in the order, from the exclusive right of the Bureau to book or reserve freight or cargo space on any ocean going vessel for the carriage of such goods from any port in or outside Tanzania to any destinantion specified in the Order. 
(2) The Minister may make regulation for the better carrying out of the purposes and provisions of this Act -

(a) prescribing the conditions and terms upon which any specified facilities or services or categories of facilities or services within the scope of the functions of the Bureau shall be provided to public and other persons;

(b) prescribing procedures relating to freight bookings;

(c) prescribing fees, rates and other charges in connection with freight operations;

(d) prescribing forms to be used for any purpose unter this Act;

(e) prescribing anything which may be prescribed under this Act;

(f) providing for any matter which, in the opinion of the Board, is necessary to provide for the efficient performance of the functions of the Bureau.

(3) Regulations made or orders given under this section shall be published in the $\mathrm{Ga}$ zette:

Provided that where regulations or orders are made which are not of general application, the Board may, in addition to or in lieu of publication in the Gazette, publish the regulations or orders in such am manner as will, in the opinion of the Board, ensure the contents of the regulations or orders coming to the notice of the persons or category of persons in respect of which they apply and of the members of the public who might be affected by such regulations or orders. 